\title{
PENGARUH TAMPILAN VISUAL WEBSITE BANK BNP TERHADAP KEPERCAYAAN VISITOR
}

\author{
Merdy Agustianto ${ }^{1}$, Agus Sachari ${ }^{2}$, Agung Eko Budiwaspada ${ }^{3}$ \\ 1,2,3 Fakultas Seni Rupa dan Desain, Institut Teknologi Bandung \\ merdy.agustianto@gmail.com ${ }^{1}$, aasachari@gmail.com², agungebw83@yahoo.com ${ }^{3}$
}

\begin{abstract}
Abstrak
Dalam industri jasa keuangan, termasuk perbankan, kepercayaan merupakan faktor yang paling berpengaruh terutama untuk mengambil keputusan dalam menetapkan pilihannya kepada salah satu perusahaan. Kepercayaan juga menjadi penting di dalam ranah internet, terutama ketika berbicara mengenai sebuah website. Melalui tampilan visual website, visitor akan membentuk persepsi terhadap website yang dikunjunginya. Ketika persepsi positif terbentuk di dalam diri visitor, maka ia tidak ragu untuk melakukan tindakan nyata kepada penyedia layanan website seperti membagikan data pribadi atau melakukan transaksi. Penelitian ini dilakukan untuk mengetahui pengaruh tampilan visual website PT Bank Nusantara Parahyangan Tbk. (Bank BNP) menggunakan alat ukur VisAWI (simplicity, diversity, colorfulness, dan craftmanship) terhadap kepercayaan visitor. Penelitian ini menggunakan sequential explanatory mixed method. Metode pengumpulan data kuantitatif yang digunakan pada penelitian ini adalah survei dengan menggunakan alat bantu kuesioner yang disebar ke 135 responden yang memiliki usia 23-38 tahun. Sedangkan metode pengumpulan data kualitatif yang digunakan adalah wawancara terstruktur. Hasil analisa data menunjukkan bahwa tampilan visual website Bank BNP berpengaruh $42,1 \%$ terhadap kepercayaan visitor. Selain itu, tampilan visual Bank BNP juga membentuk persepsi visitor akan kinerja bank tersebut dalam dunia nyata. Dari hasil penelitian diketahui bahwa hanya craftmanship saja yang mempunyai pengaruh yang positif dan signifikan terhadap kepercayaan visitor dibandingkan dengan elemen lainnya.
\end{abstract}

Kata kunci: tampilan visual, website, kepercayaan, perbankan, VisAWI

\begin{abstract}
In the financial service industry, including banking, trust is the most influential factor for making decisions in choosing a company to cooperate with. Trust also becomes significant to the use of the internet, specifically websites. Through the visual appearances of a website, a visitor will form perceptions of the website. When positive perceptions are formed, a visitor will not hesitate to take action, such as sharing personal data or making transactions with the website providers. This research was conducted to determine the influence of visual appearances of the Bank BNP website on visitor trust using VisAWI (simplicity, diversity, colorfulness, and craftsmanship). The method used in this study is a sequential explanatory mixed method. The quantitative data were collected through a survey using a questionnaire tool distributed to 135 respondents who were 23-38 years old, while the qualitative data were collected through structured interviews. The data analysis showed that the visual appearances of the website had an effect of $42.1 \%$ on visitors' trust. Visual appearances of the Bank BNP website also form visitors' perceptions of bank performance in the real world. It also can be concluded that only website craftsmanship that has a positive and significant influence on visitors' trust.
\end{abstract}

Keywords: visual appearance, website, trust, banking, VisAWI 


\section{PENDAHULUAN}

Seiring dengan perkembangan teknologi informasi dan komunikasi, tren penggunaan internet di Indonesia mengalami peningkatan dari tahun ke tahun. Menurut survei yang dilakukan pada tahun 2017 oleh Asosiasi Penyelenggara Jasa Internet Indonesia (APJII) berjudul Penetrasi \& Perilaku Pengguna Internet Indonesia, pengguna internet di Indonesia mencapai 143,26 juta jiwa atau 54,68\% dari total populasi penduduknya (gambar I.1). Angka pengguna internet ini menunjukkan peningkatan setiap tahunnya.

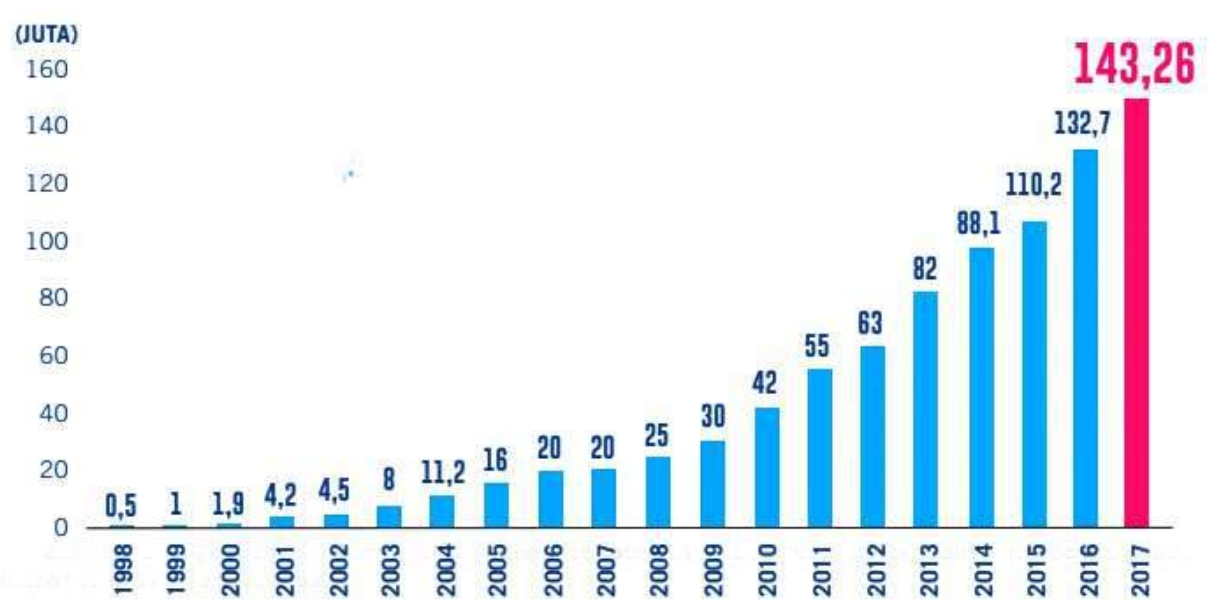

Gambar 1. Grafik peningkatan pengguna internet di Indonesia dari tahun ke tahun. [Sumber: Asosiasi Penyelenggara Jasa Internet Indonesia, 2017]

Dengan kenaikan pengguna internet, perbankan menjadi salah satu sektor industri yang terkena arus digitalisasi. Internet menggeser kebutuhan masyarakat kepada pelayanan perbankan yang cepat, mudah dan dapat dikendalikan (PricewaterhouseCoopers Indonesia, 2018). Mereka mulai memilih mengakses lewat gadget untuk mendapatkan informasi ataupun layanan perbankan yang mereka inginkan dibandingkan datang ke cabang bank. Menyadari adanya pergeseran kebutuhan masyarakat, pelaku industri perbankan mulai berinvestasi dan berinovasi ke digital banking. Salah satu inovasi yang dilakukan adalah dengan menggeser kanal transaksi nasabah dari kantor cabang ke kanal digital. Sebanyak 66\% dari perbankan di Indonesia melihat strategi digital sebagai bagian dari strategi korporasi (PricewaterhouseCoopers Indonesia, 2018). Tujuan pengembangan ke arah digital ini adalah untuk meningkatkan pengalaman nasabah (customer experience) (44\%), meningkatkan revenue (32\%) dan menekan biaya-biaya (14\%).

Bergesernya layanan perbankan ke digital banking, membuat website perusahaan menjadi hal krusial untuk dimiliki oleh institusi perbankan sebagai platform utama untuk dalam ruang lingkup online corporate communication (Garcia dkk., 2017). Melalui website perusahaan, masyarakat dapat mencari informasi mengenai sebuah bank dengan mudah menggunakan akses internet. Dalam perkembangannya, website bank bukan hanya digunakan sebagai media informasi akan tetapi juga menjadi portal bagi konsumen untuk melakukan berbagai transaksi perbankan. Otoritas Jasa Keuangan (OJK) sebagai regulator perbankan mewajibkan perusahaan jasa keuangan, termasuk 
perbankan, untuk memiliki website yang tertulis dalam POJK (Peraturan Otoritas Jasa Keuangan) Nomor 8/POJK.04/2015 tentang Situs Web Emiten Atau Perusahaan Publik dengan pertimbangan untuk meningkatkan transparansi sekaligus untuk meningkatkan akses pemegang saham serta pemangku kepentingan lainnya akan informasi yang aktual dan terkini serta sebagai bentuk penerapan prinsip tata kelola perusahaan yang baik oleh perusahaan perbankan. Dengan adanya sanksi dari peringatan tertulis sampai dengan pencabutan izin usaha dari OJK menandakan bahwa keberadaan website merupakan bagian penting yang harus dimiliki dan dikelola oleh perusahaan jasa keuangan dengan sebaik mungkin. Hal ini merupakan bagian dari usaha OJK untuk menjaga kepercayaan masyarakat terhadap industri jasa keuangan.

Dalam industri perbankan, kepercayaan merupakan faktor yang paling berpengaruh terutama untuk mengambil keputusan dalam menetapkan pilihannya kepada salah satu perusahaan (Flavian dkk, 2005). Kepercayaan terhadap perusahaan jasa keuangan dapat timbul dari berbagai macam segi, salah satunya dari citra perusahaan yang positif (Flavian dkk, 2005), baik dalam dunia nyata maupun digital. Kepercayaan juga menjadi penting di dalam ranah internet, terutama ketika berbicara mengenai sebuah website. Seorang visitor akan menilai website yang ia kunjungi dengan segala pengetahuan yang dimiliki untuk membentuk persepsi, baik positif atau negatif (McKnight dkk, 2002). Ketika persepsi positif terbentuk di dalam diri visitor, maka ia tidak ragu untuk melakukan tindakan nyata kepada penyedia layanan website seperti membagikan data pribadi atau melakukan transaksi, terutama ketika berinteraksi dengan sebuah website yang tidak atau kurang dikenal (McKnight dkk, 2002). Persepsi negatif sangat mudah terbentuk ketika seseorang berinteraksi dengan website yang tidak atau kurang dikenal. Oleh karenanya, penyedia layanan website harus bertindak untuk mengatasi persepsi negatif dalam upayanya membangun kepercayaan visitor pada saat mereka mengunjungi website (Friedman dkk, dalam Mcknight dkk, 2002), salah satu cara yaitu melalui tampilan visualnya. Seorang visitor akan membentuk kesan pertama pada sebuah website berdasarkan tampilan visualnya (Thielsch dan Moshagen, 2010). Kesan pertama ini yang kemudian akan mempengaruhi visitor dalam memutuskan untuk menjelajah lebih lanjut atau berpindah ke website lain (Thielsch dan Moshagen, 2010). Persepsi visual seseorang dapat dibangun melalui tampilan visual dalam waktu yang sangat singkat (Robins dan Holmes, 2007). Hal - hal tersebut menunjukkan pentingnya peranan tampilan visual pada sebuah website.

Pada tahun 2018, sektor industri perbankan di Indonesia memiliki 115 bank (Otoritas Jasa Keuangan, 2018) yang dibagi menjadi 4 kelompok, yaitu BUKU 1, BUKU 2, BUKU 3, dan BUKU 4. BUKU singkatan dari Bank Umum berdasarkan Kegiatan Usaha adalah pengelompokan bank berdasarkan kegiatan usaha yang disesuaikan dengan modal inti yang dimiliki (Otoritas Jasa Keuangan, 2016). BUKU 1 adalah kelompok bank yang memiliki modal inti sampai dengan kurang dari satu triliun rupiah; BUKU 2 adalah kelompok bank yang memiliki modal inti paling sedikit sebesar satu triliun rupiah sampai dengan kurang dari lima triliun rupiah; BUKU 3 adalah kelompok bank dengan modal ini paling sedikit lima triliun rupiah sampai dengan kurang dari tiga puluh triliun rupiah; BUKU 4 adalah kelompok bank dengan modal inti paling sedikit tiga puluh triliun rupiah. 
Semakin besar kelompok BUKU, maka kegiatan usaha jasa keuangan yang dapat dilakukan oleh bank-bank yang ada di kelompok BUKU tersebut semakin luas. Meskipun terdapat perbedaan kegiatan usaha yang dapat dilakukan oleh masing- masing BUKU, ke-115 bank ini berkompetisi di dalam medan yang sama untuk mendapat serta mempertahankan konsumennya.

Dari penjelasan yang sudah disampaikan, website perusahaan saat ini sudah diwajibkan oleh regulator untuk dimiliki oleh perusahaan perbankan. Selain itu sebuah website menjadi platform utama untuk dalam ruang lingkup online corporate communication dan juga sebagai akses masyarakat terhadap bank dalam ranah digital. Namun dalam praktiknya, tidak semua perusahaan perbankan di Indonesia membuat website perusahaannya dengan baik, terutama dalam kelompok BUKU 1 dan BUKU 2. Hal ini dapat terlihat dari desain tampilan visual website sebagian besar bank - bank yang berada dalam kelompok buku tersebut yang terlihat kurang baik dalam membuat website perusahaannya.

Penelitian ini dilakukan untuk mengidentifikasi pengaruh tampilan visual website perusahaan perbankan terhadap kepercayaan visitor mengetahui menggunakan website PT Bank Nusantara Parahyangan Tbk. (Bank BNP) sebagai objek penelitian. Bank BNP merupakan salah satu bank umum di Indonesia yang berkantor pusat di Kota Bandung yang telah berdiri sejak 18 Januari 1972. Bank BNP melakukan beberapa upaya serius dalam meningkatkan pelayanannya terutama dalam menghadapi arus digitalisasi dengan melakukan perbaikan-perbaikan di ranah digital, salah satunya dengan melakukan perbaikan terhadap website perusahaannya, termasuk tampilan visual serta penambahan fitur-fitur. Perbaikan website ini dilakukan pada pertengahan tahun 2017. Website Bank BNP terbaru dapat dilihat pada gambar 2. Pengukuran tampilan visual dalam penelitian ini menggunakan alat ukur estetika VisAWI (Visual Aesthetic of Website Inventory).

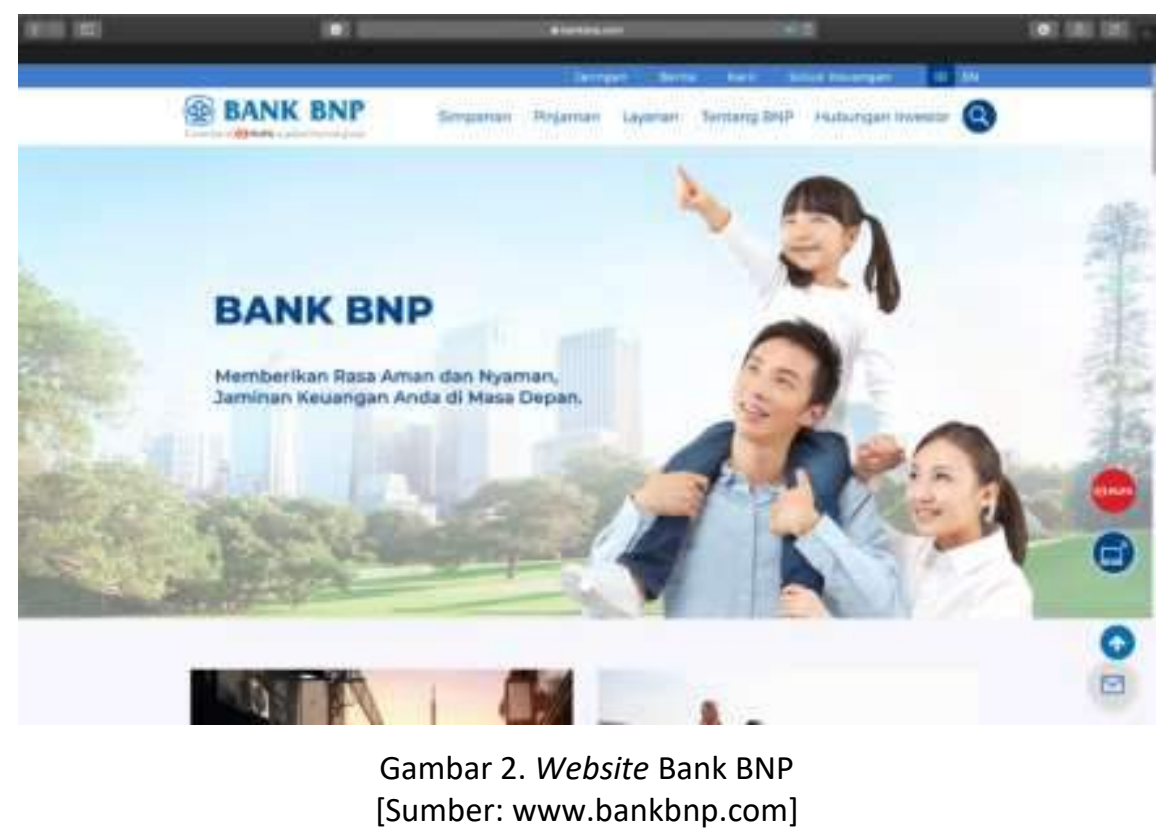


VisAWI (Visual Aesthetic of Website Inventory) merupakan alat ukur khusus untuk menilai estetika visual sebuah website dari persepsi pengguna akhir atau pengunjung yang dikembangkan oleh Moshagen dan Thielsch (2010). VisAWI menggunakan konstruksi multidimensi dan multiple-item dalam mengukur estetika visual. Dalam mengembangkan dan melakukan validasi VisAWI, Moshagen dan Thielsch melakukan 7 seri penelitian dengan total sampel sebanyak 2027 responden. Sebuah kuesioner versi pendahuluan meliputi 96 butir pernyataan diciptakan berdasarkan pengumpulan analisa dari penelitian-penelitian sebelumnya mengenai tampilan visual dengan mempertimbangkan faktor-faktor atribut antar muka yang dapat mempengaruhi persepsi visual serta mengandalkan metode wawancara para ahli (desainer website, seniman, dan psikolog dengan pengetahuan di human-computer interaction) dan pengguna akhir. Ujicoba dilakukan pada beberapa website dan dengan saran dari para ahli, terciptalah versi final dari VisAWI terdiri dalam 4 sub variabel, yaitu simplicity, diversity, colorfulness dan craftmanship. VisAWI meliputi 18 butir pernyataan dengan menggunakan skala Likert. Dari penjelasan tersebut, penelitian ini juga dilakukan untuk mencari pengaruh dari website simplicity, diversity, colorfulness dan craftmanship terhadap kepercayaan visitor website Bank BNP terhadap kepercayaan visitor.

\section{METODE PENELITIAN}

Penelitian ini menggunakan sequential explanatory mixed method yang mengumpulkan dan menganalisa data kuantitatif disambung dengan data kualitatif untuk membantu menjelaskan hasil dari proses kuantitatif di dalam satu proses penelitian (Creswell, 2014). Dalam penelitian ini, metode kuantitatif dilakukan untuk mengidentifikasi pengaruh tampilan visual berdasarkan alat ukur VisAWI terhadap kepercayaan visitor. Metode kuantitatif menggunakan teknik survei dengan alat ukur berupa kuesioner yang dianalisa dengan uji statistik. Sedangkan metode kualitatif dilakukan untuk membantu mendapatkan pemahaman lebih lanjut akan hasil yang didapatkan dari metode kuantitatif. Metode kualitatif menggunakan teknik wawancara yang dianalisa dengan interpretasi teks.

\subsection{Paradigma Penelitian}

Paradigma pada penelitian ini dapat dlihat pada gambar 3. Website memiliki 3 (tiga) elemen penting, salah satunya adalah estetika website yang tercermin dari tampilan visualnya. Estetika visual website dilihat dari persepsi pengguna akhir atau pengujung website memiliki beberapa sub variabel yaitu simplicity, diversity, colorfulness, craftmanship yang terangkum dalam alat ukur VisAWI (Moshagen dan Thielsch, 2010). Kepercayaan memiliki beberapa variabel yaitu disposition to trust (yang memiliki sub variabel faith in humanity dan trusting stance), institution-based trust (yang memiliki sub variabel structural assurance dan situational normality), trusting belief (yang memiliki sub variabel benevolence, competence dan integrity), dan trusting intention (yang memiliki sub variable willingness to depend dan subjective probability of depending) yang pada akhirnya akan menimbulkan trust related behaviors. Paradigma penelitian ini bertujuan untuk menggambarkan variable-variabel yang akan diteliti. 


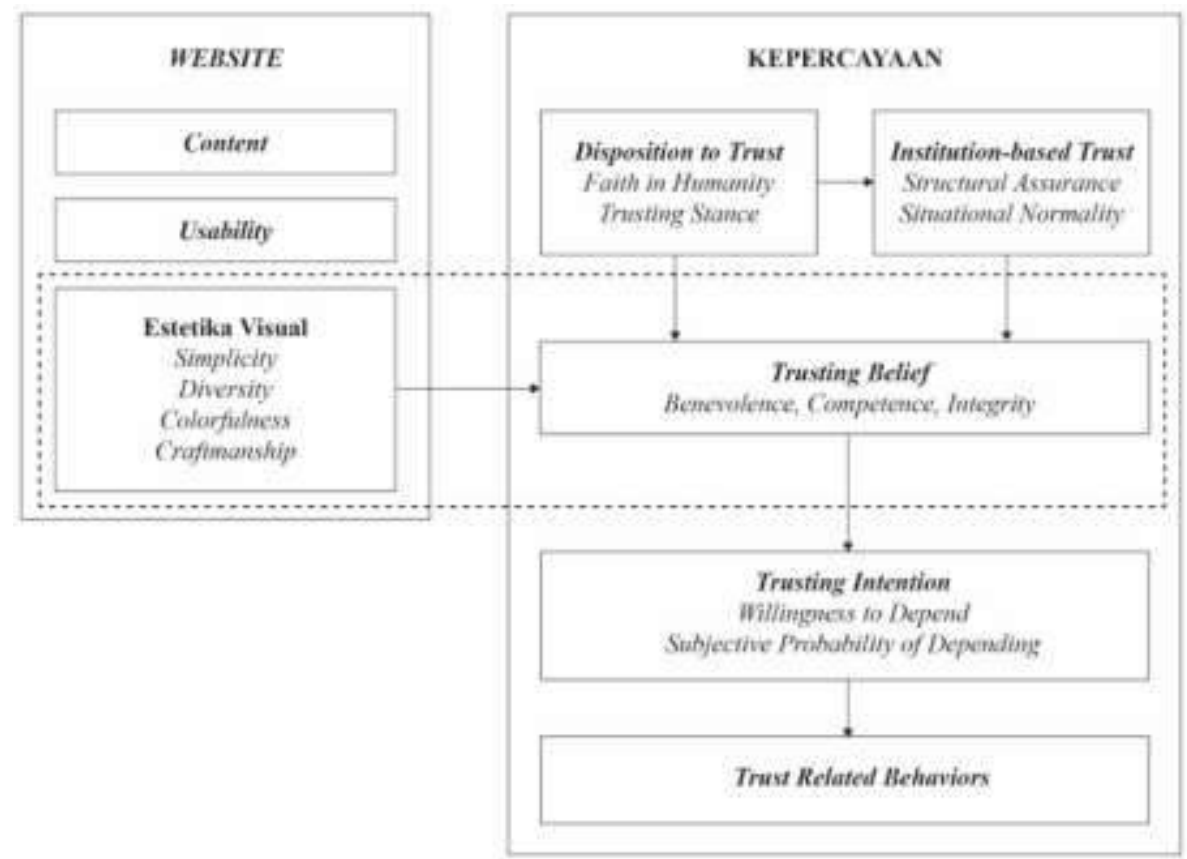

Gambar 3. Paradigma Penelitian [Sumber: Dokumen Merdy dkk]

Berdasarkan paradigma pemikiran pada gambar 3, maka penelitian ini fokus pada peran estetika pada tampilan visual website dalam membentuk kepercayaan, terutama pada pembentukan trusting belief sebagai karakteristik pembentuk kepercayaan (McKnight dan Chervany, 2000; Rompf, 2012).

\subsection{Teknik Pengumpulan Data}

Metode pengumpulan data kuantitatif yang digunakan pada penelitian ini adalah survei dengan menggunakan alat bantu kuesioner dengan skala likert yang sudah disusun untuk mendapatkan data-data dari responden. Kuesioner/angket merupakan teknik pengumpulan data yang dilakukan dengan cara memberi seperangkat pertanyaan atau pernyataan tertulis kepada responden untuk dijawab (Sugiyono, 2018). Pembuatan kuesioner dilakukan dengan menggunakan variabel tampilan visual VisAWI (Visual Aesthetic of Website Inventory) yang dikembangkan oleh Moshagen \& Thielsch (2010) dan variabel kepercayaan Web Trust Model yang dikembangkan oleh McKnight (2002).

Data kuantitatif dalam penelitian ini didapat dengan penyebaran kuesioner ke responden. Penyebaran kuesioner dalam penelitian ini dilakukan secara online. Pemilihan penyebaran kuesioner secara online dilakukan karena kecepatan waktu serta rendahnya biaya yang dibutuhkan untuk menyebarkannya, data dapat diakses kapan saja secara real time menggunakan jaringan, serta laporan data yang dapat langsung dikonversi ke dalam bentuk Microsoft Excel, sehingga meniadakan kesalahan perpindahan data dari formulir ke dokumen pengolahan. Responden dalam penelitian ini juga dipilih berdasarkan kriteria fasih dalam penggunaan internet, sehingga penggunaan kuesioner online tidak akan membingungkan atau merepotkan mereka dalam mengisinya. Melalui kuesioner online, responden dapat menjawab pertanyaan 
sesuai dengan jadwal dan cara mereka sendiri, dan bahkan dapat mengisi kuesioner pada satu waktu, berhenti, dan melanjutkannya kembali hingga selesai. Di samping itu, responden juga akan lebih terbuka dalam menjawab pertanyaan-pertanyan yang bersifat pribadi seperti pendidikan, pekerjaan, ataupun status ekonominya. Formulir kuesioner dibuat dengan Google Form, kemudian disebarkan melalui pesan pada aplikasi whatsapp. Pembuatan formulir kuesioner dalam Google Form ini terdapat pengaturan jenis jawaban seperti pilihan jawaban singkat, jawaban berganda, skala, sampai jawaban terbuka. Kemudian formulir yang sudah dibuat dapat diatur sedemikian rupa sehingga responden tidak akan melewatkan pertanyaan yang harus dijawab, maka kemungkinan terjadinya error, seperti pertanyaan terlewat pada saat pengisian menjadi sangat rendah.

Sedangkan teknik pengumpulan data kualitatif yang akan digunakan pada hasil penelitian ini adalah wawancara terhadap responden yang akan didasari oleh pembagian demografi dari responden tahap kuantitatif. Singh dalam Hakim (2013) menyatakan bahwa ada dua jenis wawancara yaitu wawancara formal dan informal. Dalam penelitian ini akan digunakan cara wawancara formal. Responden akan diberikan sejumlah susunan pertanyaan yang sudah disiapkan sebelumnya dengan tujuan untuk mendapatkan pemahaman lebih dalam akan data yang dihasilkan pada tahap kuantitatif.

\subsection{Sampel Penelitian}

Populasi dari penelitian ini adalah masyarakat generasi milenial. Generasi milenial sangat menikmati menggunakan teknologi. Generasi milenial merupakan generasi pertama yang memiliki teknologi dan internet pada saat umur masih muda dan bertumbuh seiring dengan berkembangnya teknologi tersebut (Djamasbi dkk., 2010). Selain itu, Asosiasi Penyedia Jasa Internet Indonesia (APJII) menyatakan bahwa pengguna internet terbanyak berasal dari kelompok umur $19-34$ tahun sebesar 49,52\%, diikuti dengan kelompok umur 35 - 54 tahun sebesar 29,55\%. Jumlah responden yang digunakan dalam penelitian ini adalah 135 responden menggunakan metode purposive sampling untuk tahap kuantitatif dan 6 responden untuk tahap kualitatif. Dalam penelitian ini kriteria dari sampel yang ditentukan adalah pria dan wanita yang aktif menggunakan internet lebih dari 2 jam setiap hari di luar penggunaan media sosial. Hal ini bertujuan agar sampel yang dipilih merupakan orang-orang yang memang sudah memiliki pengalaman cukup dengan lingkungan internet sehingga data yang diperoleh akan dapat menjawab fenomena yang terjadi.

\subsection{Analisa Data}

Metode kuantitatif dalam penelitian ini diuji dengan menggunakan analisa uji statitiska sebagai sarana untuk menganalisa data yang telah diperoleh. Untuk mempermudah dalam analisa data, maka proses pengolahan data dilakukan dengan menggunakan pengolah data SPSS. Proses analisa data dimulai dengan dilakukan uji validasi, uji reabilitas dan uji asumsi klasik pada instrumen penelitian. Hasil dari jawaban kuesioner kemudian dianalisis dengan metode regresi linear sederhana dan berganda. Sedangkan data tahap kualitatif dianalisa dengan menggunakan interpretasi teks oleh peneliti. 


\section{HASIL DAN PEMBAHASAN}

\subsection{Hasil Pengolahan Data}

\subsubsection{Uji Validitas}

Pengujian validitas yang digunakan adalah korelasi Pearson melalui SPSS versi 23, dengan hasil tertera pada Tabel 1. Berdasarkan data tersebut, semua variabel dalam penelitian ini valid karena nilai korelasi Pearson diatas 0.3 dengan $p$-value dibawah 0.05 dan dapat digunakan untuk pengolahan data selanjutnya.

Tabel 1. Hasil Uji Validitas Variabel Penelitian

[Sumber: Hasil pengolahan data SPSS versi 23]

\begin{tabular}{|c|c|c|c|}
\hline Variabel & Indikator & Korelasi Pearson & Signifikansi ( $p$-value) \\
\hline \multirow{5}{*}{ Simplicity } & S1 & 0.754 & 0.000 \\
\hline & $S 2$ & 0.780 & 0.000 \\
\hline & S3 & 0.785 & 0.000 \\
\hline & S4 & 0.790 & 0.000 \\
\hline & S5 & 0.765 & 0.000 \\
\hline \multirow{5}{*}{ Diversity } & D1 & 0.798 & 0.000 \\
\hline & $\mathrm{D} 2$ & 0.743 & 0.000 \\
\hline & D3 & 0.823 & 0.000 \\
\hline & D4 & 0.746 & 0.000 \\
\hline & D5 & 0.810 & 0.000 \\
\hline \multirow{4}{*}{ Colorfulness } & $\mathrm{C} 1$ & 0.824 & 0.000 \\
\hline & $\mathrm{C} 2$ & 0.817 & 0.000 \\
\hline & $\mathrm{C} 3$ & 0.813 & 0.000 \\
\hline & $\mathrm{C} 4$ & 0.879 & 0.000 \\
\hline \multirow{4}{*}{ Craftmanship } & CR1 & 0.807 & 0.000 \\
\hline & CR2 & 0.795 & 0.000 \\
\hline & CR3 & 0.770 & 0.000 \\
\hline & CR4 & 0.847 & 0.000 \\
\hline \multirow{9}{*}{ Kepercayaan } & TC1 & 0.766 & 0.000 \\
\hline & TC2 & 0.680 & 0.000 \\
\hline & TC3 & 0.823 & 0.000 \\
\hline & TB1 & 0.825 & 0.000 \\
\hline & TB2 & 0.837 & 0.000 \\
\hline & TB3 & 0.850 & 0.000 \\
\hline & TI1 & 0.856 & 0.000 \\
\hline & $\mathrm{TI} 2$ & 0.861 & 0.000 \\
\hline & $\mathrm{TI3}$ & 0.824 & 0.000 \\
\hline
\end{tabular}

\subsubsection{Uji Reabilitas}

Hasil uji reliabilitas ini tertera pada Tabel 2 dan Tabel 3. Tabel 2 menunjukkan bahwa hasil dari uji reliabilitas secara keseluruhan adalah reliable, karena nilai Cronbach's Alpha (0.894) lebih besar dari 0.7. Tabel 3 menunjukkan uji reliabilitas per sub variabel tampilan visual dan variabel kepercayaan bahwa semua variabel reliabel karena memiliki nilai Cronbach's Alpha diatas 0.7. Data menunjukkan bahwa alat ukur yang digunakan reliabel sehingga dapat digunakan dalam penelitian ini. 
Tabel 2. Hasil uji reliabilitas keseluruhan

[Sumber: Hasil pengolahan data SPSS versi 23]

\begin{tabular}{|c|c|}
\hline Cronbach's Alpha & N of Items \\
\hline 0.894 & 5 \\
\hline
\end{tabular}

Tabel 3. Hasil uji reliabilitas sub variabel tampilan visual dan kepercayaan [Sumber: Hasil pengolahan data SPSS versi 23]

\begin{tabular}{|l|c|}
\hline \multicolumn{1}{|c|}{ Variabel } & Nilai Cronbach's Alpha \\
\hline Simplicity & 0.874 \\
\hline Diversity & 0.859 \\
\hline Colorfulness & 0.883 \\
\hline Craftmanship & 0.848 \\
\hline Kepercayaan & 0.890 \\
\hline
\end{tabular}

\subsubsection{Uji Asumsi Klasik}

Uji Asumsi klasik yang dilakukan pada penelitian ini meliputi uji normalitas, uji multikolinearitas dan uji heterokedastisitas. Uji normalitas yang digunakan dalam penelitian ini adalah dengan melihat histogram (gambar 4), P-P Plot (gambar 5), dan uji Kolmogorov-Smirnov (Tabel 4).

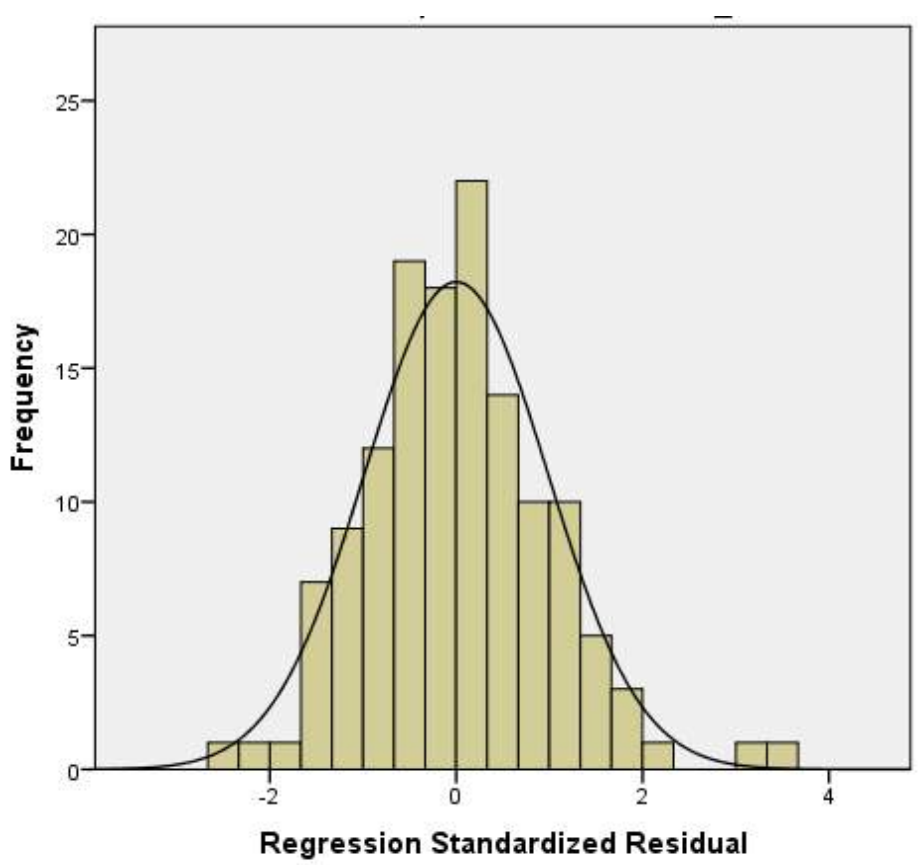

gambar 4. Histogram residu

[Sumber: Hasil pengolahan data SPSS versi 23] 


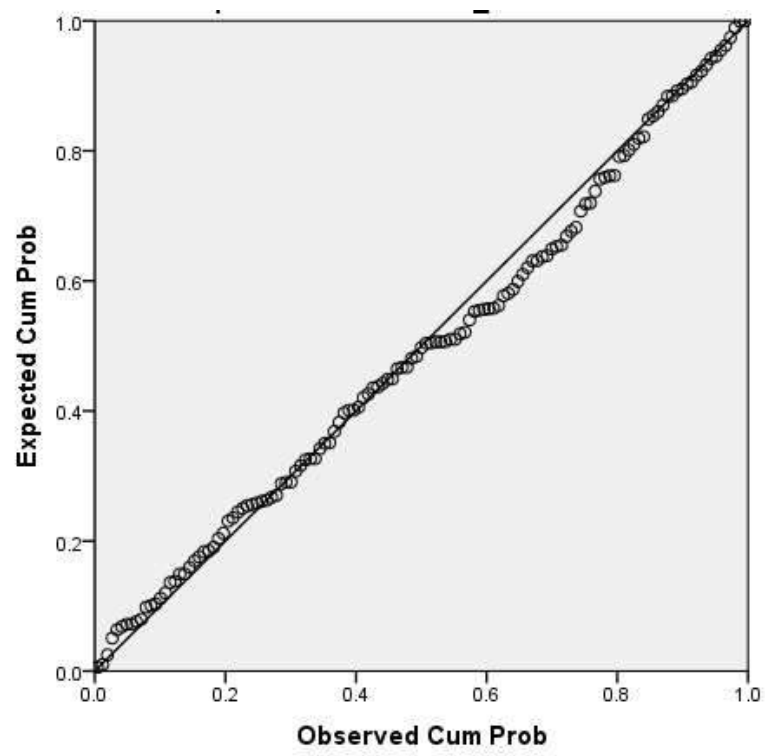

Gambar 5. Normal P-P Plot Residu

[Sumber: Hasil pengolahan data SPSS versi 23]

Berdasarkan gambar 4, dapat dilihat bahwa distribusi dari residu pada penelitian ini adalah normal, karena bentuk dari distribusinya merupakan distribusi normal (seperti lonceng yang simetris). Hal ini juga didukung oleh normal $P$ - $P$ plot yang menggambarkan plot dari residunya hampir menempel seluruhnya dengan garis trend (gambar 5). Lebih jauh, hasil dari uji Kolmogorov-Smirnov (Tabel 4) menunjukkan residu berdistribusi normal karena nilai $p$-value lebih besar dari 0 .

Tabel 4. One-Sample Kolmogorov-Smirnov Test

[Sumber: Hasil pengolahan data SPSS versi 23]

\begin{tabular}{|l|l|}
\hline Asymp. Sig. (2-tailed) (p-value) & $0.200^{c, d}$ \\
\hline
\end{tabular}

Penelitian ini menggunakan nilai VIF untuk uji multikolinearitas, dengan hasil tertera pada Tabel 5. Pada penelitian ini tidak terdapat masalah multikolinearitas karena nilai VIF masih dibawah 5.

Tabel 5. Nilai VIF

[Sumber: Hasil pengolahan data SPSS versi 23]

\begin{tabular}{|c|c|}
\hline Model & VIF \\
\hline S_MEAN & 2.417 \\
\hline D_MEAN & 2.921 \\
\hline C_MEAN & 1.958 \\
\hline CR_MEAN & 3.480 \\
\hline
\end{tabular}


Pada uji heterokedasitisitas, penelitian ini menggunakan uji Korelasi Rank Spearman, dengan hasil tertera pada Tabel 6. Pada penelitian ini tidak terdapat masalah heterokedastisitas karena nilai signifikansi atau $p$-value semuanya lebih besar daripada 0.05 , yang berarti varian dari residu bersifat homokedastisitas. Penelitian ini memenuhi asumsi semua uji klasik, sehingga regresi linear berganda dapat digunakan.

Tabel 6. Nilai VIF

[Sumber: Hasil pengolahan data SPSS versi 23]

\begin{tabular}{|c|c|}
\hline Variabel & P-value \\
\hline Simplicity & 0.808 \\
\hline Diversity & 0.506 \\
\hline Colorfulness & 0.572 \\
\hline Craftmanship & 0.323 \\
\hline Kepercayaan & 0.388 \\
\hline
\end{tabular}

\subsubsection{Hasil Regresi Linear Sederhana}

Pada tabel 7 terdapat besaran pengaruh variabel independen (tampilan visual) terhadap variabel dependen (kepercayaan) yang dilihat dari nilai adjusted $R^{2}$ yang ditampilkan yaitu sebesar 0,421 atau $42,1 \%$.

Tabel 7. Hasil regresi linear sederhana

[Sumber: Hasil pengolahan data SPSS versi 23]

\begin{tabular}{|c|c|c|c|}
\hline$R$ & R Square & Adjusted R Square & Sig. \\
\hline $0.652^{\mathrm{a}}$ & 0.425 & 0.421 & 0.000 \\
\hline
\end{tabular}

Nilai pengaruh dari masing - masing sub variabel daam VisAWI dapat dilihat dari nilai koefisien dari kolom B (koefisien). Jika dilihat dari tabel tersebut, seluruh sub variabel memiliki angka mendekati 1 , dengan demikian dapat dimaknai bahwa semua sub variabel tampilan visual website Bank BNP memiliki pengaruh positif terhadap variabel kepercayaan. Namun hanya sub variabel craftsmanship saja yang signifikan dikarenakan nilai $p$-value (sig.) lebih kecil dari 0.05. Sedangkan sub variabel lainnya (simplicity, diversity, dan colorfulness) tidak signifikan dikarenakan nilai $p$-value lebih besar dari 0.05 .

Tabel 8. Hasil regresi linear berganda

[Sumber: Hasil pengolahan data SPSS versi 23]

\begin{tabular}{|l|c|c|}
\hline \multicolumn{1}{|c|}{ Model } & B & Sig. \\
\hline Simplicity & 0.050 & 0.565 \\
\hline Diversity & 0.062 & 0.464 \\
\hline Colorfulness & 0.139 & 0.060 \\
\hline Craftmanship & 0.375 & 0.001 \\
\hline
\end{tabular}




\subsection{Pembahasan}

Pengolahan data dengan regresi linear sederhana menunjukkan bahwa tampilan visual website Bank BNP berpengaruh secara positif dan signifikan terhadap kepercayaan visitor sebesar $42,1 \%$ (adjusted $\mathrm{R}^{2}=0.421$ ), sisanya $(57,9 \%$ ) dipengaruhi dipengaruhi oleh faktor-faktor lain yang tidak dijelaskan dalam model penelitian ini seperti brand awareness, reputasi, konten, usability atau faktor lainnya. Hal ini juga menunjukkan adanya model hubungan linear antara tampilan visual website Bank BNP sebagai variabel independen dan kepercayaan visitor sebagai variabel dependen. Menurut Costa dan Kallick (2010), manusia pada dasarnya merupakan mahluk visual yang mampu menyerap 36.000 gambar setiap menitnya yang membuat sebanyak 80 - 90\% informasi yang diterima oleh otak, berasal dari mata. Hal tersebut membuat mata memiliki kontribusi pada pengelolaan informasi, kepekaan psikologis dan intelektual, termasuk pada persepsi manusia (Costa dan Kallick, 2010; Ward, 2015), sehingga tampilan visual sebuah website akan berpengaruh terhadap persepsi manusia termasuk di dalamnya kepercayaan sebagai hasil dari penilaian subjektif. Hasil temuan pada penelitian ini juga sejalan dengan pendapat-pendapat yang dikemukakan oleh Patzer dalam Praxmer dan Rossiter (2009), Mitra (2014) yang menunjukkan bahwa ada hubungan yang linear antara tampilan visual dengan persepsi seseorang. Oleh karenanya dapat dikatakan bahwa semakin baik tampilan visual sebuah website, semakin baik juga pengaruhnya terhadap persepsi seseorang, termasuk kepercayaan. Dari hasil wawancara juga ditemukan bahwa tampilan visual website Bank BNP juga membentuk persepsi visitornya terhadap citra (image) dan kinerja bank tersebut dalam dunia nyata, seperti modern, profesionalisme, sistem pengelolaan, kompetensi, pola kerja, dan lain - lain. Hal ini dapat dimaknai bahwa tampilan visual website yang baik diyakini sebagai cerminan citra dan kinerja yang baik juga dari penyedia layanan website. Melalui tampilan visual website Bank BNP yang terlihat modern, terstruktur, simple, clean, menggunakan teknologi terkini, menunjukkan kinerja yang modern, efektif, efisien, jelas, tidak bertele-tele dan tidak membingungkan dan inovatif.

Dari hasil pengolahan data juga diketahui bahwa sub variabel simplicity, diversity, dan colorfulness memiliki pengaruh yang positif terhadap kepercayaan visitor, namun tidak signifikan. Hanya sub variabel craftmanship yang memiliki pengaruh positif dan signfikan terhadap kepercayaan visitor. Alasan yang disampaikan oleh responden adalah website craftmanship merupakan kemampuan untuk mengintegrasikan dengan keahlian dan ketelitian semua elemen-elemen desain yang ada untuk menampilkan tampilan visual sebuah website. Website craftmanship juga dipercaya responden sebagai sebuah penentu baik atau tidaknya hasil akhir dari tampilan visual sebuah website. Melalui craftmanship juga, akan tercermin kinerja perusahaan. Jika implementasi tampilan visualnya yang baik, tertata, rapi dan teliti, hal tersebut juga menjadi cerminan pola kerja pada perusahaan tersebut di mata visitor.

Craftmanship dapat dicirikan sebagai sebuah integrasi yang terampil dan koheren dari semua dimensi-dimensi desain yang relevan, meliputi implementasi ide-ide (konsep) artistik secara harmonis dengan keahlian dan ketelitian serta penggunaan teknologi terkini (Moshagen dan Thielsch, 2010). Dari penjelasan tersebut dapat diartikan bahwa 
craftmanship merupakan proses penggabungan seluruh elemen-elemen artistik dari sebuah website dengan keahlian dan ketelitian, termasuk di dalamnya elemen VisAWI yang lain seperti tata letak yang digunakan (simplicity), keragaman visual yang ditampilkan (diversity) dan kombinasi warna-warna yang dipilih (color) untuk menentukan hasil akhir dari tampilan visual sebuah website. Website craftmanship menjadi berpengaruh secara signifikan karena elemen tersebut yang pada akhirnya akan menentukan baik atau tidaknya hasil akhir dari tampilan visual website yang dilihat oleh visitor dan akan membentuk persepsi mereka. Persepsi inilah yang menentukan kepercayaan visitor terhadap website tersebut.

Sesuai dengan prinsip psikologi Gestalt, manusia mempersepsikan sebuah benda sebagai satu kesatuan struktur yang utuh dibandingkan per elemen individual (Graham, 2008; Alsudani dan Cassey, 2009; Wageman dkk., 2012). Begitu juga halnya dengan cara manusia membentuk persepsi akan sebuah website. Manusia melihat website sebagai kesatuan tampilan visual yang utuh dibandingkan masing-masing elemen (misalnya jenis, ukuran, warna, alignment, penempatan huruf yang digunakan; jenis, bentuk, warna, ketebalan, resolusi, penempatan tulisan, penempatan gambar; ukuran, penempatan tombol yang digunakan; dan lainnya) dari website tersebut. Kemampuan craftmanship yang akan menentukan sebuah website akan terlihat menarik atau tidak secara keseluruhan dengan mengintegrasikan seluruh elemen - elemen website.

Website craftmanship juga memiliki indikator tentang penggunaan teknologi terkini yang akan membuat sebuah website memiliki tampilan visual yang sesuai dengan perkembangan jamannya serta menghindari impresi kuno. Hal tersebut juga dapat membuat visitor lebih mudah untuk mempercayai penyedia layanan website. Semakin visitor merasa website yang dikunjunginya sesuai dengan perkembangan teknologi, semakin mudah juga mereka percaya pada website tersebut. Namun hal ini hanya berlaku untuk pengguna yang berpengalaman dan memiliki cukup pengetahuan untuk memahami dan mengevaluasi sesuai dengan pemahaman teknologi tinggi yang ada pada dirinya (Karvonen, 2000).

\section{KESIMPULAN}

Berdasarkan penelitian yang telah dilakukan didapat sebuah data bahwa tampilan visual website Bank BNP memiliki pengaruh positif dan signifikan dalam membentuk kepercayaan visitor-nya sebesar 42,1\%, sisanya (57,9\%) dipengaruhi dipengaruhi oleh faktor-faktor lain yang tidak dijelaskan dalam model penelitian ini. Hasil ini memberikan pemahaman bahwa tampilan visual website Bank BNP memiliki peranan cukup besar dalam mempengaruhi kepercayaan visitor. Hal ini didasari juga dengan cara manusia mempersepsikan tampilan visual. Manusia melihat sesuatu sumber yang memiliki penampilan yang menarik secara visual akan dipersepsikan sebagai sumber yang baik dan dapat dipercaya. Tampilan visual sebuah website juga membentuk persepsi visitor akan kinerja bank tersebut dalam dunia nyata. Tampilan visual website yang modern, terstruktur, simple, clean akan menunjukkan kinerja bank yang modern, efektif, jelas, tidak bertele - tele dan tidak membingungkan. Oleh karena itu, dalam membuat website 
perbankan desain tampilan visual website sebaiknya diberikan perhatian khusus karena memiliki pengaruh positif dan signifikan terhadap kepercayaan visitor.

Dari hasil penelitian juga dapat disimpulkan bahwa website craftmanship mempunyai pengaruh yang positif dan signifikan terhadap kepercayaan visitor dibandingkan dengan elemen lainnya dalam alat ukur VisAWI. Website craftmanship merupakan proses penggabungan seluruh elemen-elemen artistik dari sebuah website dengan keahlian dan ketelitian, termasuk di dalamnya elemen VisAWI yang lain seperti tata letak yang digunakan (simplicity), keragaman visual yang ditampilkan (diversity) dan kombinasi warna-warna yang dipilih (color) untuk menentukan hasil akhir dari tampilan visual sebuah website. Website craftmanship menjadi berpengaruh secara signifikan karena elemen tersebut yang pada akhirnya akan menentukan baik atau tidaknya hasil akhir dari tampilan visual website yang dilihat oleh visitor dan akan membentuk persepsi mereka. Persepsi inilah yang menentukan kepercayaan visitor terhadap website tersebut. Penggunaan teknologi terkini juga menjadi bagian dari website craftmanship yang akan membuat visitor lebih mudah untuk mempercayai penyedia layanan website dan menghindari impresi ketinggalan jaman. Semakin visitor merasa website yang dikunjunginya modern dalam penggunaan teknologi, semakin mudah juga mereka percaya pada website tersebut. Namun hal ini hanya berlaku untuk pengguna yang berpengalaman dan memiliki cukup pengetahuan untuk memahami dan mengevaluasi sesuai dengan pemahaman teknologi tinggi yang ada pada dirinya

Berdasarkan hasil penelitian ini, terdapat beberapa saran untuk penelitian selanjutnya, di antaranya penggunaan alat ukur tampilan visual. Pada penelitian ini pengukuran tampilan visual website VisAWI. Penelitian selanjutnya dapat melakukan pengukuran tampilan visual website dan pengaruhnya terhadap kepercayaan dengan menggunakan pengukuran berdasarkan pakar lain. Kemudian, objek penelitian ini hanya fokus pada 1 bank, sehingga tidak dapat digeneralisasi terhadap bank lainnya. Untuk penelitian selanjutnya, dapat digunakan objek penelitian lebih banyak untuk mendapatkan gambaran secara keseluruhan dalam industri perbankan tentang pengaruh tampilan visual website terhadap kepercayaan visitor. Serta fokus penelitian ini hanya pada tampilan visual website versi desktop, sehingga pada penelitian selanjutnya dapat difokuskan pada website versi mobile.

\section{DAFTAR PUSTAKA}

Alsudani, F., Casey, M., F. 2009. The Effect of Aesthetic on Web Credibility. People and Computers XXIII.

Asosiasi Penyelenggara Jasa Internet Indonesia. 2017. Infografis Penetrasi \& Perilaku Pengguna Internet Indonesia Survey 2017, URL: https://apjii.or.id/survei2017 [Diakses pada 18 Oktober 2018]

Costa, A. L. \& Kallick, B. 2008. Learning and Leading with Habits of Mind, 16 Essential Characteristic for Success. Association for Supervision \& Curriculum Development.

Creswell, J. W. 2014. Research Design, United Kingdom: SAGE Publication, Inc. 
Djamasbi, S., Tullis, T., Siegel, M. 2010. Generation Y, Web Desain, and Eye Tracking. International Journal of Human-Computer Studies, 68 (5), pp.307-323.

Flavian, C., Miguel, G., dan Eduardo, T. 2005. The Influence of Corporate image on Consumer Trust, Emerald,15 (4), pp.447-470.

Garcia, M. G., Carrillo-Duran, M. V., dan Jimenez, J. L. T. 2017. Online Corporate Communication: Website Usability and Content, Journal of Communication Management, 21 (2).

Graham, L. 2008. Gestalt Theory in Interactive Media Design, Journal if Humanities \& Social Sciences, 2 (1).

Holmes, J., Robins, D. 2007. Aesthetics and Credibility in Web Site Design, Information Processing and Management, 44, pp.386-399.

McKnight, D. H., Choudhury, V., dan Kacmar, C. 2002. Developing and Validating Trust Measures for e-Commerce: An Integrative Typology, INFORMS, 13 (3), pp.334359.

Mitra, B., Webb, M., dan Wolfe, C. 2014. Audience responses to the physical appearance of television newsreader, Journal of Audience \& Reception Studies, 11 (2), 4557.

Moshagen, M., Thielsch, M. T. 2010. Facets of Visual Aesthetics, International Journal of Human-Computer Studies, 68 (10), pp.689-709.

Otoritas Jasa Keuangan. 2016. Peraturan Otoritas Jasa Keuangan Nomor 6 /Pojk.03/2016 Tentang Kegiatan Usaha Dan Jaringan Kantor Berdasarkan Modal Inti Bank, data diperoleh melalui situs internet, http://www.ojk.go.id/id/kanal/perbankan/regulasi/peraturan-

ojk/Documents/Pages/pojk-kegiatan-usaha-dan-jaringan-kantor-berdasarkanmodal-inti-bank/SALINAN-POJK.6\%20BUKU.pdf. [Diakses pada 4 Maret 2018]

Otoritas Jasa Keuangan. 2016. Peraturan Otoritas Jasa Keuangan Nomor 8 /POJK.04/2015 TENTANG Situs Web Emiten Atau Perusahaan Publik, URL: http://www.ojk.go.id/id/regulasi/otoritas-jasa-keuangan/peraturanojk/Documents/Pages/Peraturan-OJK-Nomor-8-POJK-04-2015-tentang-SitusWeb-Emiten-atau-Perusahaan-Publik/peraturan-ojk-nomor-8-pojk-04-2015tentang-situs-web-emiten-atau-perusahaan-publik\%2001.pdf. [Diakses pada 4 Maret 2018]

Otoritas Jasa Keuangan. 2017. Statistik Perbankan Indonesia., data diperoleh melalui situs internet, http://www.ojk.go.id/id/kanal/perbankan/data-danstatistik/statistik-perbankan-indonesia/Documents/Pages/Statistik-

Perbankan-Indonesia---Desember-2017/SPI\%20Desember\%202017.pdf. [Diakses pada 14 Maret 2018]

Praxmer, S., Rossiter, J. R. 2009. Physically Attractive Presenter and Persuasion: An Experimental Investigation of Alternative Explanation for the "Patzer Effect", $8^{\text {th }}$ International Conference on Research in Advertising (ICORIA).

PricewaterhouseCoopers Indonesia. 2018. 2018 Indonesia Banking Survey. URL https://www.pwc.com/id/en/publications/assets/financialservices/2018indonesia-banking-survey.pdf. [Diakses pada 18 Oktober 2018] 
PricewaterhouseCoopers Indonesia. 2018. Digital Banking in Indonesia 2018. URL https://www.pwc.com/id/en/publications/assets/financialservices/digitalbanking-survey-2018-pwcid.pdf. [Diakses pada 18 Oktober 2018]

Rompf, S. 2012. Trust and Adaptive Rationality Towards a New Paradigm in Trust Research. Disertasi Program Doktor IImu Sosial: Universitas Mannheim.

Sabar, S. 2013. What's a Gestalt?, Gestalt Review, 17(1), 6-34.

Sugiyono. 2018. Metode Penelitian Kuantitatif, Kualitatif dan $R \& D$, Bandung: Alfabeta.

Ward, M. O., Grinstein, G., dan Keim, D. 2015. Interactive Data Visualization, CRC Press, New York, 73 - 74.

Wagemans, J., Kubovy, M., Peterson, M. A., Elder, J. H., Palmer, S. E., dan Singh, M. 2012. A Century of Gestalt Psychology in Visual Perception: I. Perceptual Grouping and Figure-Ground Organization, American Psychology Association, 138 (6), pp.1172-1217. 